\title{
THE ADJUVANT EFFECT OF A TUBERCLE BACILLARY LIPID ON THE ANTIBODY RESPONSE OF RABBITS TO SHEEP RED CELLS
}

\author{
A. W. Pound and G. E. O'Rourke \\ Department of Pathology, Medical School, University of Queensland, Brisbane, Australia
}

THE inclusion of certain lipid fractions of Mycobacterium tuberculosis, in particular the wax $\mathrm{D}$, in water-in-paraffin-oil emulsions as a vehicle for an antigen in the aqueous phase augments the resulting level of circulating antibody in the animals injected. It also may lead to hypersensitivity of the delayed type to a protein antigen, and promote the development of certain "autoimmune" conditions (White, Coons and Connolly, 1955; Munoz, 1964; White, $1967 a$ and $c$ ). This may account, in whole or in part, for the adjuvant properties of intact dead bacilli (Freund, 1951, 1956). Injection of the antigen in water-in-paraffin-oil emulsion without any mycobacterial component has a lesser adjuvant effect (Freund, 1951; White et al.), whereas injection of the "wax D" alone in saline suspension with an antigen is said to have no adjuvant effect (White et al.).

On the other hand, a saline suspension of a similar tubercle bacillary wax on repeated intraperitoneal injection into guinea-pigs with tubercle bacillary protein, ovalbumin or horse serum albumin (Pound, 1955, 1958) enhanced both the resulting levels of precipitating antibody and the skin reactions obtained on intradermal testing with the antigens; the skin reactions had the characteristics of Arthus phenomena. These observations are contrary to other reports that injection of a tubercle bacillary wax, prepared in the same manner, together with tubercle bacillary protein, ovalbumin or picryl chloride leads to delayed type hypersensitivity to these antigens (Raffel, 1948; Raffel and Forney, 1948; Raffel et al., 1949) but to insignificant increases in complement-fixing antibody titres. Notwithstanding these as yet unresolved discrepancies it is apparent that the lipid may vary or alter the character of the immunological response as well as augment its intensity. The species of immunoglobulin involved may also be varied by the action of the lipid (White, 1967b).

The experiments reported in this paper show that intravenous injection of lipid into rabbits augments the immune response to red cells injected intravenously at the same time.

\section{MATERIALS AND METHODS}

Rabbits. The rabbits were from the Royal Brisbane Hospital (strain $\mathrm{BH}$ ) or from the Medical School (strain $\mathrm{H}$ ) and weighed $2 \frac{1}{2}-3 \mathrm{~kg}$.

Tubercle bacillary lipid. The lipid was prepared as previously described (Pound, 1955) from heat-killed $M$. tuberculosis strain PN grown on the medium of Dorset and Henley, and corresponded to the " hard wax" fraction (Anderson, 1927); it was designated batch II. It

Received 16 Nov. 1970; accepted 17 Mar. 1971.

J. MED. MICROBIOL.-VOL. 4 (1971) 
was emulsified by grinding in saline, made up to a suitable concentration and subjected to ultrasonication.

Sheep red cells. Sheep erythrocytes were obtained by bleeding a sheep or from the Commonwealth Serum Laboratories, Melbourne. The sheep red cells in Alsever's solution were stored at $3^{\circ} \mathrm{C}$. When required, the cells were separated by the centrifuge, washed three times with 20 times their volume of saline, and 1.0 per cent. or 0.5 per cent. suspensions of packed red cells were prepared in saline.

Antibody titrations. Rabbit serum complement was inactivated by heating at $56^{\circ} \mathrm{C}$ for 20 min. Haemagglutinin was assayed by the addition of a 0.5 per cent. suspension of sheep erythrocytes to equal volumes of doubling dilutions of serum set up in Wassermann tubes or by the microtitre system (Tyrrell, 1967). Titres were read after standing for $2 \mathrm{hr}$ at room temperature.

Haemolysin titres followed the same procedures. Fresh guinea-pig serum was the source of complement, and the determined optimum amount was added after the red cells. Titres were read, after incubation at $37^{\circ} \mathrm{C}$ for $1 \mathrm{hr}$, as the highest dilution of serum before addition of the red cells or the red cells and complement that led to agglutination or haemolysis of the red cells.

Experiment $I$. Three groups of four rabbits $(\mathrm{H})$ were bled on 2 consecutive days and again 2 days later immediately before being given an intravenous injection of $1.25 \mathrm{ml}$ per $\mathrm{kg}$ of a 1 per cent. suspension of sheep red cells in saline into the ear-vein. Four animals were given $10 \mathrm{mg}$ tubercle bacillary lipid in $1 \mathrm{ml}$ saline intravenously within $30 \mathrm{~s}$ after the sheep red cells, and four were given the $10 \mathrm{mg}$ lipid $24 \mathrm{hr}$ after the red cells. The rabbits were then bled once every 2 nd day for 14 days to obtain serum. The haemagglutinin and haemolysin titres were determined on each specimen of serum by the microtitre method.

Experiment II. Two groups of five rabbits $(\mathrm{BH})$ were given $1 \mathrm{ml}$ per $\mathrm{kg}$ of a 1 per cent. suspension of sheep red cells in saline intravenously via the ear vein. One group received red cells alone, the other group $10 \mathrm{mg}$ tubercle bacillary lipid in $1 \mathrm{ml}$ saline $30 \mathrm{~min}$. before the red cells. The rabbits were bled at the outset and at intervals of 2 days until the 14th day after injection of the red cells. The sera were collected and the haemolysin titres determined (tube system).

Experiment III. In the same way three groups of five rabbits (BH) were given an intravenous injection of $1 \mathrm{ml}$ per $\mathrm{kg}$ of a 1 per cent. suspension of sheep red cells. One group received red cells alone, the second group red cells followed by $10 \mathrm{mg}$ lipid in $1 \mathrm{ml}$ saline 4 days later and the third group the same dose of lipid 6 days later. The rabbits were bled at the outset and at 2-day intervals until the 14th day. The sera were collected and titrated for haemolysin (tube system).

\section{RESULTS}

The antibody titres obtained in each experiment are set out in the tables.

\section{Haemolysin titres after injection of sheep red cells}

The natural haemolysin to sheep red cells in the serum of these rabbits is, on the average, active to a dilution of about 1 in 32 . On the 2 nd day after injection of sheep red cells (experiments I, II and III, tables I and II) no change in the titre was found. On the 4th day, the mean titre was increased, but the increase is of doubtful significance statistically. The antibody titre increased rapidly on the 6th and 8th days to a maximum between the 8th and 10th days, after which it fell slightly by the 14th day. No significant difference was found between the results of the animals injected with red cells alone in experiments I, II and III, which are therefore combined to draw the graph (fig. 1) of the variation of mean haemolysin titre with time after injection of red cells. 


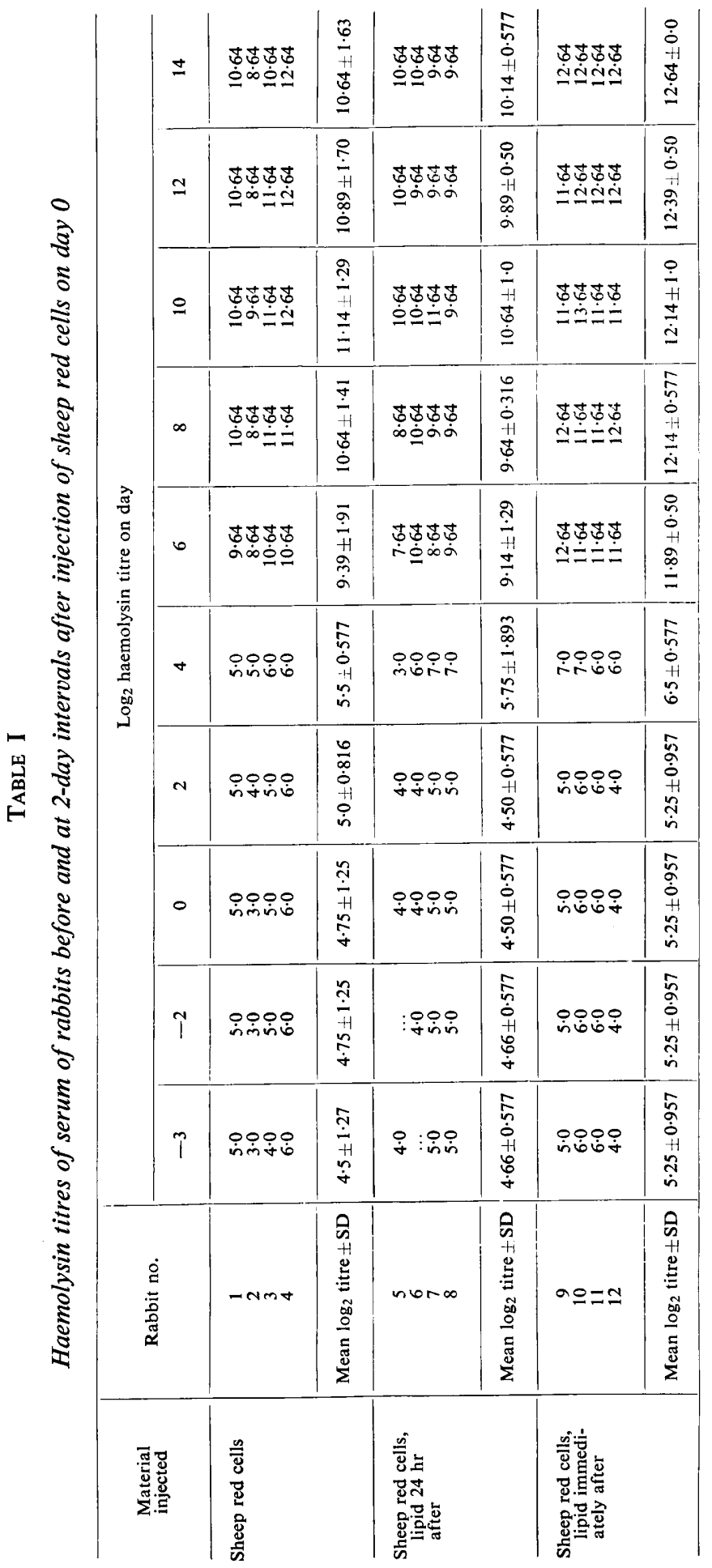


A. W. POUND AND G. E. O'ROURKE

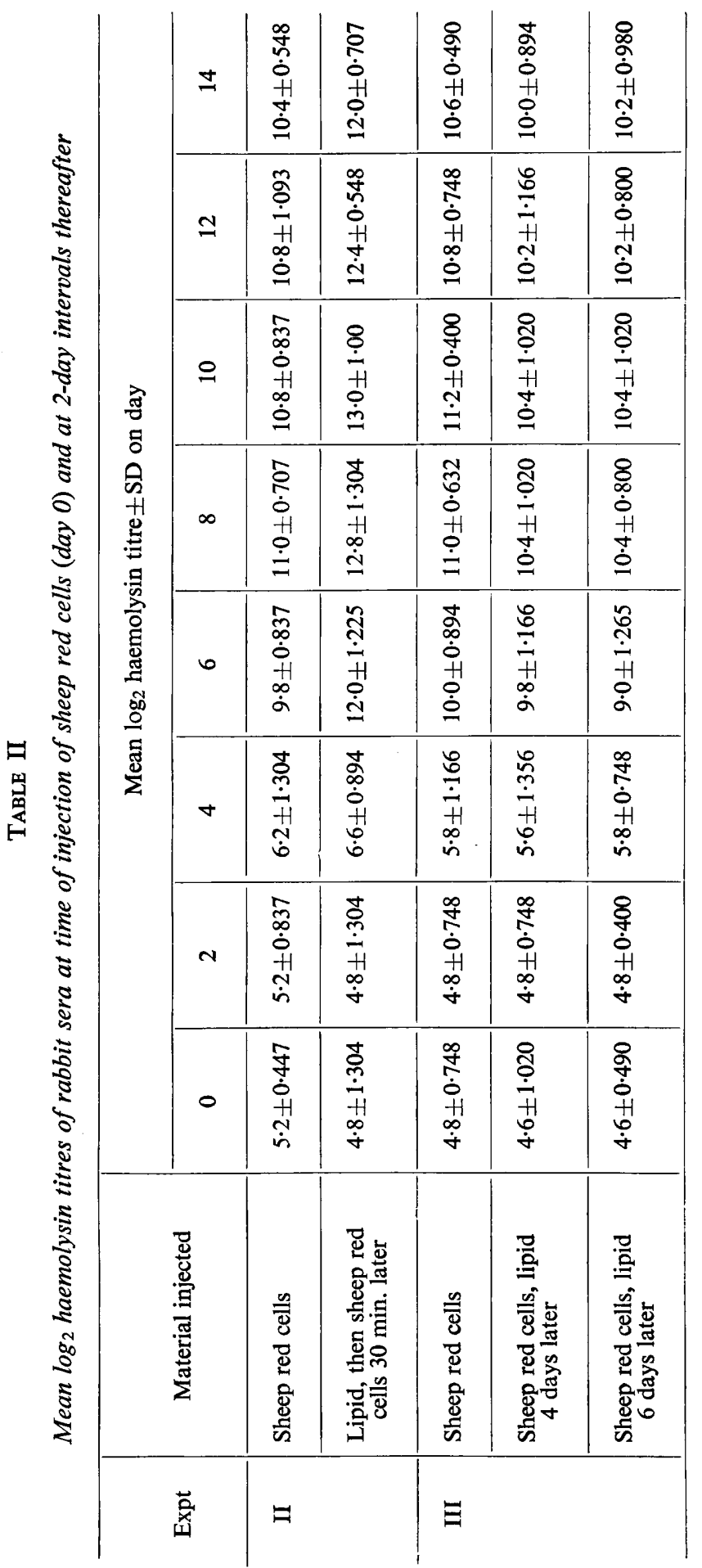




\section{Effect of lipid on haemolysin titres after injection of sheep red cells}

Injection of the lipid intravenously at about the same time as the red cells, that is immediately after the red cells in experiment $\mathrm{I}$, or $30 \mathrm{~min}$. before the red cells in experiment II, altered the antibody response. No change in titre was

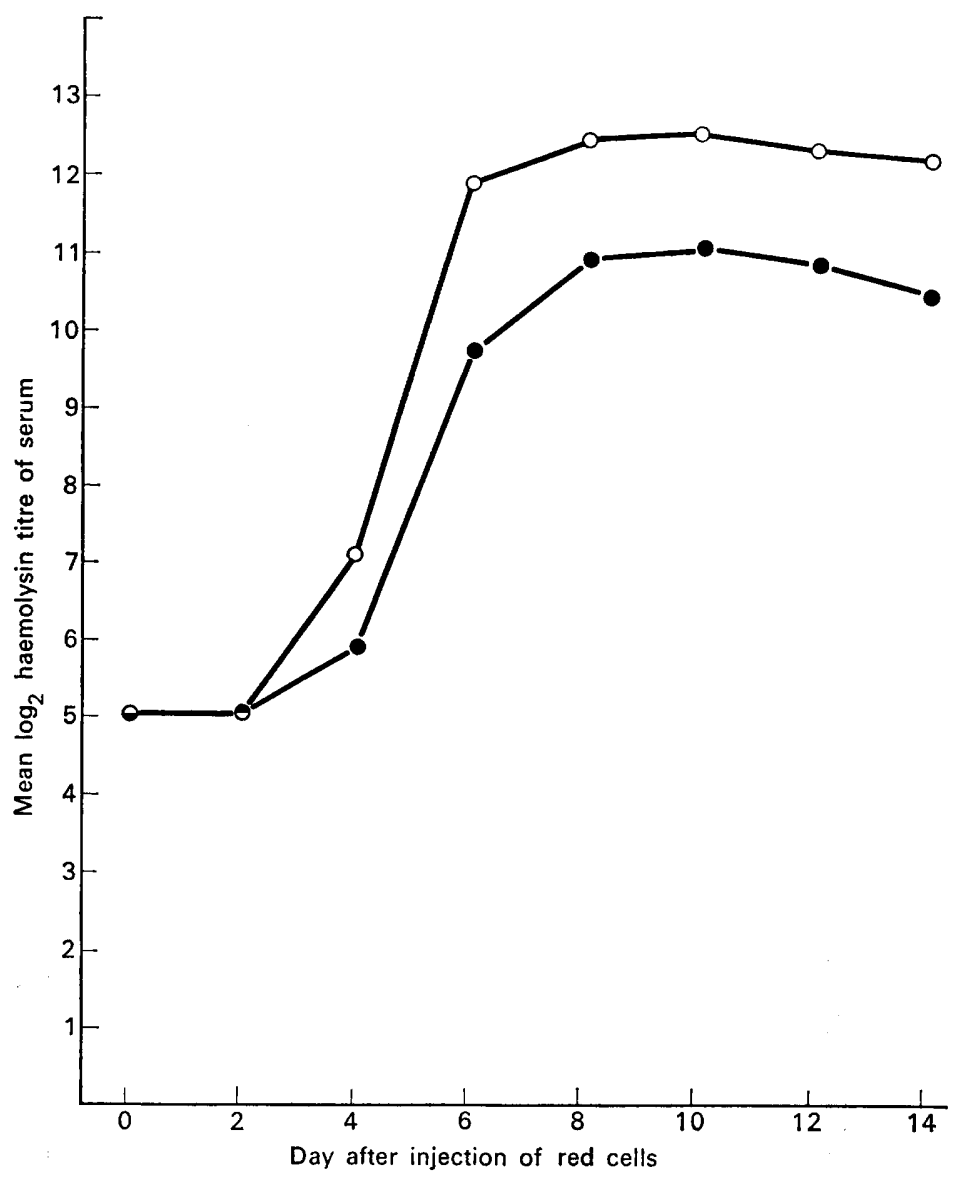

FIG. 1.-Mean haemolysin titres of rabbits at varying times after injection of sheep erythrocytes. - Animals injected with erythrocytes only: combined data of experiments I, II and III. O Animals injected with $10 \mathrm{mg}$ lipid at the same time as the red cells: combined data of experiments I and II.

found on the 2nd day after injection of the red cells. On the 4th day the antibody titre was increased and the titre was higher than that found at this time in the animals given red cells alone. The titre increased rapidly on the 6th and 8th days to a maximum between the 8th and 10th days, after which it declined slightly by the 14th day. Analysis of variance of the results of experiment I (table I) showed that the titres of the animals given lipid immediately after the red cells were significantly higher than in the animals treated with red cells 


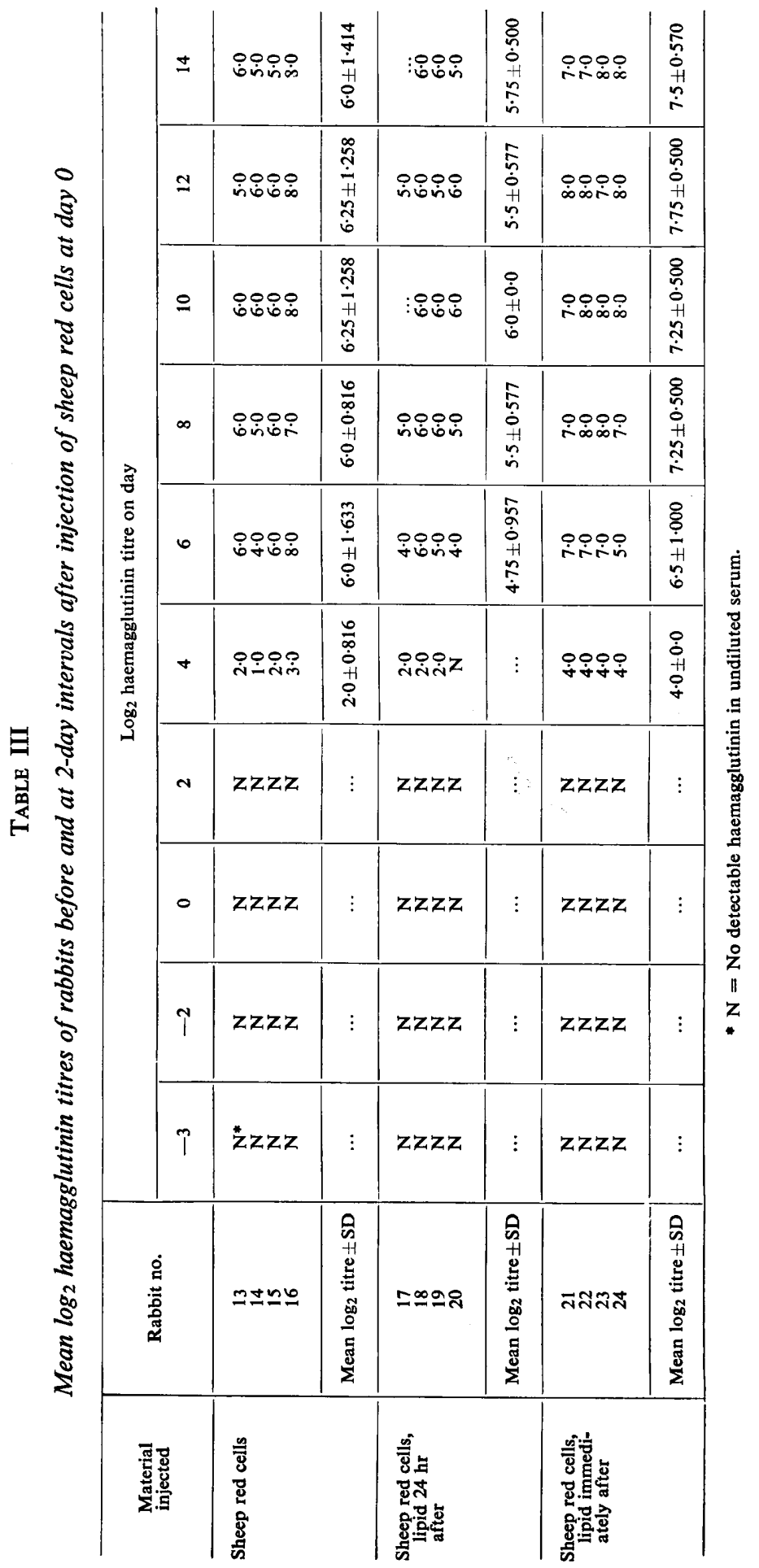


alone on the 6th, 12th and 14th days, but did not reach the 5 per cent. level of significance on the 8th and 10th days.

The titres of the animals given lipid immediately after the red cells in experiment II (table II) were significantly increased at the 6th, 8th, 10th, 12th and 14th days.

There was no significant difference between the haemolytic antibody levels of the lipid-treated animals in experiments I and II, which are therefore combined in the graph of the antibody response of animals treated with lipid at the same time as the red cells (fig. 1). The small increase in the antibody levels on

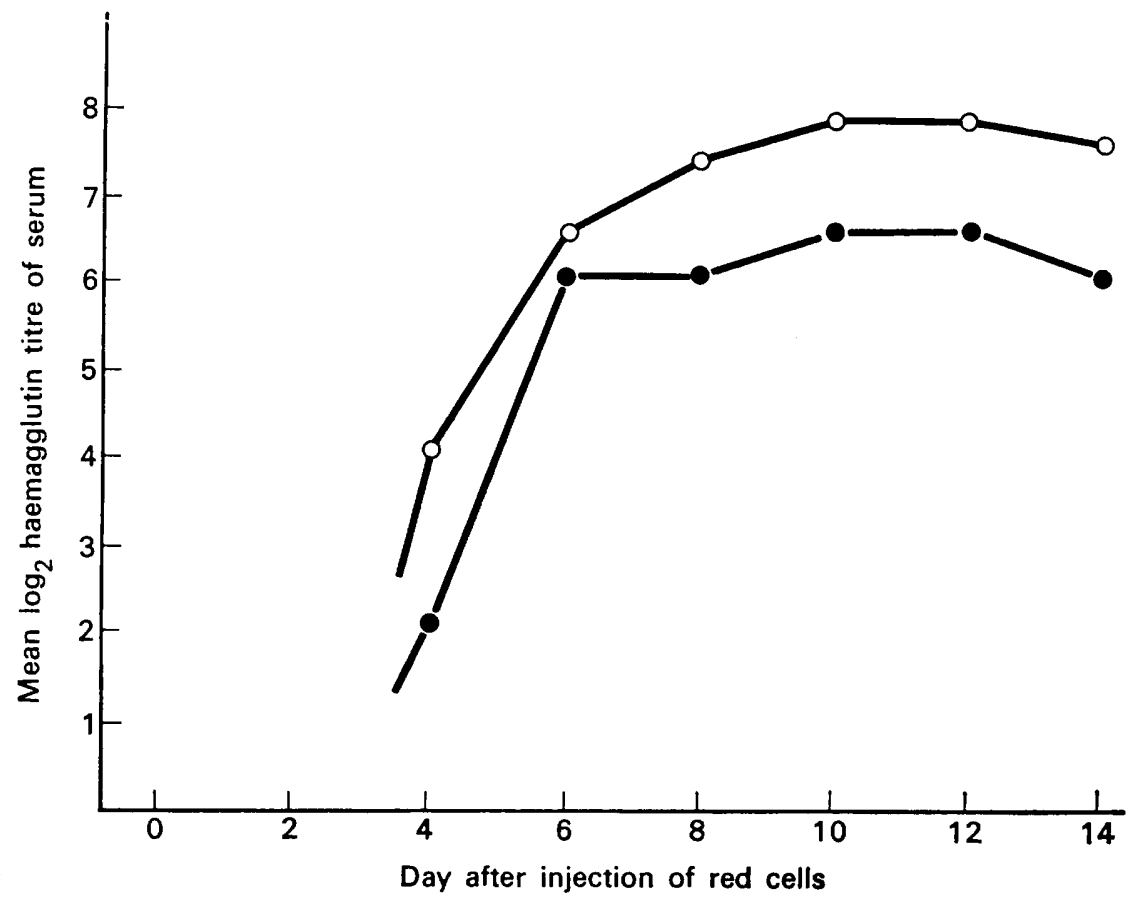

FIG. 2.-Mean haemagglutinin titres of rabbits at varying times after injection of sheep erythrocytes. - Animals injected with erythrocytes only, experiment I. O Animals injected with $10 \mathrm{mg}$ lipid at the same time as the red cells, experiment $I$.

the 4th day is of course to be correlated with the rapidly increasing titres in the succeeding few days, because clearly if the rate of antibody formation is increased antibody will be detected at an earlier time; there is no evidence that the time of appearance of antibody is significantly advanced from these results.

On the other hand, when the lipid was injected $24 \mathrm{hr}$ after the red cells (experiment I) or 4 or 6 days after the red cells (experiment III), the antibody titre did not differ significantly at any time from that in animals given an injection of red cells alone.

\section{Haemagglutinin titres}

A similar effect of the lipid was found on the production of agglutinating antibody to sheep red cells (experiment I, table III). Such an agglutinating 
antibody does not normally appear in the serum of these rabbits to a titre of 2. After intravenous injection of sheep red cells, agglutinin appeared on the 4th day and increased to a maximum about the 8th or 10th day. In animals given an intravenous injection of the lipid at the same time, the titre on the 4th day was higher. The titre increased to a maximum at about the 8 th or 10th day, and the titre obtained is higher than that in the animals given the red cells alone. The increase is statistically significant on the 4 th, 8th, 10th, 12th and 14th days. Injection of the lipid $24 \mathrm{hr}$ after the red cells had no effect on the agglutinating titre at any stage (fig. 2).

\section{Discussion}

These results show that a single intravenous injection of a saline emulsion of the wax fraction of the lipids from tubercle bacilli into rabbits augmented the antibody response if it was given immediately before or after intravenous injection of sheep red cells, but did not do so if it was injected after $24 \mathrm{hr}$ or longer. The time of first detection of the antibody rise was not significantly advanced. The peak titres were higher, but appeared at about the same time after injection of these antigens, and the rate of decline of the antibody titre did not appear to be altered. The logical interpretation is that the rate of production of serum antibody was increased rather than that the higher titres were due to a prolonged period of antibody production. If it is assumed that the species of antibody protein remains unchanged, this implies either an increased number of antibody-producing cells, or an increased rate of synthesis in these cells, or both.

The fact that the lipid augments the antibody response to sheep red cells when it is injected intravenously as an emulsion in saline strongly suggests a stimulation of the cells involved at some point in the chain of events leading to antibody synthesis, and obviates the complicating effect of large granulomata produced by other methods of injection. An apparent adjuvant effect on active haemolysin production might arise by independent stimulation of the cells producing the natural haemolysin in these animals, but this has been shown not to occur (O'Rourke and Pound, 1971).

After intravenous injection the lipid is probably taken up by reticuloendothelial cells at a very rapid rate. This leads to disseminated small epithelioidcell granulomata, predominantly in the lungs, and a generalised hyperplasia of the reticulo-endothelial cells. The changes are conspicuous after multiple injections of the lipid (O'Rourke and Pound), but are significant after a single injection (unpublished data). The lesions commence as focal collections of monocytic cells and become epithelioid in character after 3 or 4 days; later they regress slowly. It seems unlikely that the red cells can be incorporated into these lesions. Although the stimulated reticulo-endothelial cells might have an increased ability to phagocytose red cells, it is improbable that this is relevant when the lipid is injected at any time after the red cells, which are not retained in the blood for more than a few minutes.

The cellular phenomena involved in active antibody formation to sheep red cells, as well as to other particulate antigens, are well documented (La Via, 
1964). Injected erythrocytes are phagocytosed very rapidly by reticuloendothelial cells, mainly in the liver and spleen; few remain in circulation after $10 \mathrm{~min}$. (Ingraham, 1955). Precursors of plasma cells appear within 2 days and develop rapidly into mature plasma cells as antibody production increases during the next 2-4 days.

The lack of effect of the lipid when it is injected 1, 4 and 6 days after the red cells therefore implies that it does not directly stimulate the plasma cells immediately concerned in active antibody synthesis once their differentiation is under way. In addition, the lack of effect at $24 \mathrm{hr}$ after injection of the antigen suggests that any changes induced in reticulo-endothelial cells at this time do not influence the development of those cells. At this stage all the injected red cells will have been phagocytosed and the question arises whether reticuloendothelial cells that have phagocytosed red cells are still subject to stimulation by the lipid.

When the lipid is injected at the same time as the red cells, it is clear that the active antibody-synthesising cells do become involved. In mice, injection of a similar tubercle bacillary lipid augments haemolysin titres to injected sheep cells and the number of antibody-forming plaques counted by the Jerne technique is increased (Koga et al., 1969). It seems likely that in these rabbits the number of plaques would be increased. However, it also seems likely that this is not due to a direct effect on the antibody-producing cells, but is mediated by an indirect general effect, certainly operating at an early stage in their differentiation and possibly through a function of the reticulo-endothelial cells.

The increased antibody titres are not as high as those obtained when the antigen is injected with dead tubercle bacilli or into a tuberculous animal (Lewis and Loomis, 1924, 1925); nor can this be expected. On the one hand large granulomata form at the injection sites that may influence phenomena by several mechanisms (Pound, 1958; Munoz, 1964). On the other hand, in the tuberculous animal the reticulo-endothelial cells are subject to continuous active stimulation.

\section{SUMMARY}

Rabbits were given an intravenous injection of sheep red cells. Some received red cells only, others were given, at the same time or at $24 \mathrm{hr}$ or at 4 or 6 days after the red cells, an intravenous injection of a saline emulsion of a tubercle bacillary lipid. The haemolysin and haemagglutinin titres against sheep red cells were determined for serum samples taken before and at 2-day intervals after injection of red cells.

Animals given lipid at the same time as red cells showed an antibody response significantly greater in rate and magnitude than that in animals given red cells only. Lipid given $24 \mathrm{hr}$ or more after injection of red cells had no effect on the antibody response.

\section{REFERENCES}

ANDERson, R. J. 1927. The separation of lipoid fractions from tubercle bacilli. J. Biol. Chem., 74, 525. 
FREUND, J. 1951. The effect of paraffin oil and mycobacteria on antibody formation and sensitization. A review. Amer. J. Clin. Path., 21, 645.

Freund, J. 1956. The mode of action of immunologic adjuvants. Adv. Tuberc. Res., 7, 130.

INGRAHAM, J. S. 1955. Artificial radioactive antigens. III. S35-sulfanilazo-sheep red cell stromata; preparation and gross distribution in normal rabbits and mice. J. Infect. Dis., 96, 105.

Koga, T., Ishibashi, T., Sugryama, K., AND Tanaka, A. 1969. Immunological adjuvants. III. A preliminary report about the mode of action of mycobacterial adjuvants and further confirmation of adjuvant activity of acetylated wax D. Int. Archs Allergy Appl. Immun., 36, 233.

LA VIA, M. F. 1964. Primary and secondary antibody response in rats to bacterial and sheep erythrocyte antigens. J. Immun., 92, 252.

LewIs, P. A., AND LOOMIS, DOROTHY 1924. Allergic irritability. The formation of anti-sheep hemolytic amboceptor in the normal and tuberculous guinea pig. J. Exp. Med., 40, 503.

Lewis, P. A., AND LoOMIS, DOROThY 1925. Allergic irritability. II. Anaphylaxis in the guinea pig as affected by the inheritance. J. Exp. Med., 41, 327.

Munoz, J. 1964. Effect of bacteria and bacterial products on antibody response. Adv. Immun., 4, 397.

O'Rourke, G. E., AND Pound, A. W. 1971. The effects of a tubercle bacillary lipid on lymphoreticular tissue and on the natural haemolysin to sheep red cells in the rabbit. Pathology, 3, 107.

Pound, A. W. 1955. The effect of a tubercle bacillary " wax" on the response of guinea-pigs to the injection of tubercle bacillary protein. J. Path. Bact., 70, 119.

Pound, A. W. 1958. The effect of a tubercle bacillary lipid on antibody production to ovalbumin and horse serum albumin in the guinea pig. J. Path. Bact., 75, 55.

RAFFEL, S. 1948. The components of the tubercle bacillus responsible for the delayed type of " infectious" allergy. J. Infect. Dis., 82, 267.

Raffel, S., Arnaud, L. E., Dukes, C. D., And Huang, J. S. 1949. The rôle of the "wax" of the tubercle bacillus in establishing delayed hypersensitivity. II. Hypersensitivity to a protein antigen, egg albumin. J. Exp. Med., 90, 53.

RAFFEL, S., AND ForNEY, J. E. 1948. The rôle of the "wax" of the tubercle bacillus in establishing delayed hypersensitivity. I. Hypersensitivity to a simple chemical substance, picryl chloride. J. Exp. Med., 88, 485.

TYRRELL, D. A. J. 1967. Immunological methods in virology. In Handbook of experimental immunology, ed. by D. M. Weir, Oxford, pp. 788-789.

Whrte, R. G. 1967a. Role of adjuvants in the production of delayed hypersensitivity. $B r$. Med. Bull., 23, 39.

White, R. G. $1967 b$. Concepts relating to the mode of action of adjuvants. Symp. Ser. Immunobiol. Standardn, 6, 3.

WhITE, R. G. 1967c. Characterization of mycobacterial components of adjuvant mixtures. Symp. Ser. Immunobiol. Standardn, 6, 49.

White, R. G., Coons, A. H., AND Connolly, Jeanne M. 1955. Studies on antibody formation. IV. The role of a wax fraction of Mycobacterium tuberculosis in adjuvant emulsions on the production of antibody to egg albumin. J. Exp. Med., 102, 83. 